Check for updates

Cite this: RSC Adv., 2017, 7, 54852

\section{Nanocrystalline carbon coated alumina with enhanced phase stability at high temperatures}

\author{
Alexander M. Volodin, ${ }^{a}$ Alexander F. Bedilo, ${ }^{\text {ab }}$ Vladimir O. Stoyanovskii, ${ }^{a}$ \\ Vladimir I. Zaikovskii, ${ }^{\text {ac }}$ Roman M. Kenzhin, ${ }^{a}$ Ilya V. Mishakov ${ }^{\text {ad }}$ \\ and Aleksey A. Vedyagin (D) *ad
}

A comparative investigation of the phase stability at high temperatures of nanocrystalline $\mathrm{Al}_{2} \mathrm{O}_{3}$ and carboncoated $\mathrm{Al}_{2} \mathrm{O}_{3} \mathrm{CC}$ systems was performed using a set of physicochemical and spectroscopic methods. The obtained data demonstrate that the carbon coating hinders the sintering of the $\delta-\mathrm{Al}_{2} \mathrm{O}_{3}$ phase and its transformation to the $\alpha-\mathrm{Al}_{2} \mathrm{O}_{3}$ phase at $1250{ }^{\circ} \mathrm{C}$. Without the carbon coating, the $\delta-\mathrm{Al}_{2} \mathrm{O}_{3}$ sinters and becomes completely converted to corundum at noticeably lower temperatures. The stabilization of the nanosized oxide particles in the $\mathrm{Al}_{2} \mathrm{O}_{3} \mathrm{OC}$ system was shown to be the decisive factor preventing their transformation to the $\alpha-\mathrm{Al}_{2} \mathrm{O}_{3}$ phase. The thermal stability of the $\mathrm{Al}_{2} \mathrm{O}_{3} @ \mathrm{C}$ samples calcined within a range of $1180-1250{ }^{\circ} \mathrm{C}$ in an argon atmosphere followed by the calcination in air to remove the carbon coating was found to exceed that of pure $\delta-\mathrm{Al}_{2} \mathrm{O}_{3}$. Such samples are characterized by the presence of carbon-alumina interfaces, when carbon is encapsulated in small amounts at the places of contact between the oxide nanoparticles. Such interfaces hinder the sintering of alumina nanoparticles. It is important that the active sites present on the surface of the oxide core in $\mathrm{Al}_{2} \mathrm{O}_{3} \mathrm{CC}$ samples calcined in air are similar to those known for pure alumina. The high concentration of such sites after thermal treatment at elevated temperatures makes this class of materials promising for use as catalysts or catalyst supports capable of operating at high temperatures.
Received 10th August 2017 Accepted 27th November 2017 DOI: $10.1039 / \mathrm{c} 7 \mathrm{ra0} 8841 \mathrm{~h}$ rsc.li/rsc-advances shown that the rutile phase is thermodynamically unstable in the case, when the $\mathrm{TiO}_{2}$ nanoparticles smaller than $20 \mathrm{~nm}$, whereas the anatase phase is quite stable. ${ }^{11-13}$ So, the rutile formation during the temperature growth is related to the growth of $\mathrm{TiO}_{2}$ nanoparticles due to their sintering. Similar behavior was observed for $\mathrm{Al}_{2} \mathrm{O}_{3} \cdot \gamma-\mathrm{Al}_{2} \mathrm{O}_{3}$ is the most stable phase at the high specific surface area and the small particle size. The most stable bulk phase $\alpha-\mathrm{Al}_{2} \mathrm{O}_{3}$ (corundum) is formed only when the oxide particles become sufficiently large. ${ }^{14-17}$ Meanwhile, the growth of oxide nanoparticles directly contacting with each other takes place at high temperatures due to the sintering.

We have suggested that such sintering can be slowed down or even completely prevented by eliminating the direct contact between the oxide nanoparticles. This could stabilize the size of the nanoparticles and hinder the formation of the hightemperature phases (rutile and corundum for $\mathrm{TiO}_{2}$ and $\mathrm{Al}_{2} \mathrm{O}_{3}$, respectively) even at elevated temperatures. The fact that the sintering of alumina particles can be hindered by their coating with carbon is known for a long time. This concept also known as a 'carbon nanoreactor' concept was successfully applied for the stabilization of a variety of oxide systems. ${ }^{18-22}$ At the same time, in a number of recent papers it was shown that the carbon coating can be used for the synthesis of the structured and mesoporous materials based on $\mathrm{Al}_{2} \mathrm{O}_{3} \cdot{ }^{19,23}$ Earlier we have reported that the carbon coating deposited on the surface of the oxide

\footnotetext{
aBoreskov Institute of Catalysis SB RAS, Pr. Ac. Lavrentieva 5, Novosibirsk, 630090, Russian Federation. E-mail: vedyagin@catalysis.ru; Tel: +7-383-326-96-60

${ }^{b}$ Novosibirsk Institute of Technology, Kosygin Russian State University, Krasny pr. 35, Novosibirsk, 630099, Russian Federation

${ }^{c}$ Novosibirsk State University, Pirogova str. 2, Novosibirsk, 630090, Russian Federation ${ }^{d}$ National Research Tomsk Polytechnic University, Lenin Av. 30, Tomsk, 634050, Russian Federation
} 
nanoparticles can act as a nanoreactor shell. On the one hand, such coating can be penetrable for the reactant molecules from the gas $^{7,10,24,25}$ or liquid ${ }^{26}$ phases making it possible to initiate various catalytic or solid-state reactions inside the nanoreactor. Moreover, the carbon coating prevents sintering of nanoparticles inside the shell during the temperature increase and stabilizes their sizes. The anatase phase was shown to be stable for the carbon-coated titania $\mathrm{TiO}_{2} @ \mathrm{C}$ with the core-shell structure up to the temperatures as high as $750{ }^{\circ} \mathrm{C}^{25} \mathrm{It}$ is important that the $\mathrm{TiO}_{2}$ nanoparticles inside the carbon shell practically do not grow in this temperature range. At higher temperatures, the $\mathrm{TiO}_{2}$ nanoparticles are subjected to reduction by the deposited carbon.

$\gamma-\mathrm{Al}_{2} \mathrm{O}_{3}$ is a mesoporous sorbent and a catalyst support widely used in the modern chemical technology. It has high surface area and maintains it at the temperatures as high as $700-800{ }^{\circ} \mathrm{C}$. Further temperature increase results in its phase transformations accompanied by the dehydration, the nanoparticle growth and the surface area decrease. Recently reported data indicate that the carbon nanoreactor could be used to stabilize the size of the aluminum oxide nanoparticles and prevent their phase transformations. ${ }^{25}$

In this study we have analyzed the effect of the carbon coating deposited on the $\mathrm{Al}_{2} \mathrm{O}_{3}$ surface on the alumina phase transformations $(\gamma \rightarrow \delta \rightarrow \alpha)$, pore structure and state of active sites on the surface after the calcination at high temperatures.

\section{Experimental}

The $\gamma-\mathrm{Al}_{2} \mathrm{O}_{3}$ sample used as a precursor for the synthesis of all other samples was obtained by the calcination of a Condea "Pural SB-1" pseudoboehmite sample in air at $720{ }^{\circ} \mathrm{C}$ for $6 \mathrm{~h}$. The sample was heated up to the calcination temperature with a ramping rate of $1.5^{\circ} \mathrm{C} \mathrm{min}^{-1}$. The specific surface area of the precursor sample was about $210 \mathrm{~m}^{2} \mathrm{~g}^{-1}$.

To deposit the carbon coating, the $\gamma-\mathrm{Al}_{2} \mathrm{O}_{3}$ precursor was mixed with polyvinyl alcohol (PVA) in a $7: 3$ weight ratio. Then, the obtained mixture was heated in a quartz reactor in argon up to $750{ }^{\circ} \mathrm{C}$ with a ramping rate of $1.5^{\circ} \mathrm{C} \mathrm{min}{ }^{-1}$ and kept at this temperature for $6 \mathrm{~h}$.

For treatment at higher temperatures, the obtained sample was placed into a graphite crucible that was installed into a corundum tube assembled inside a tubular Starbar TSR heater. Then, the sample was heated in an argon flow with a ramping rate of $3{ }^{\circ} \mathrm{C} \mathrm{min}^{-1}$ to the desired temperature varied from 960 to $1450{ }^{\circ} \mathrm{C}$ and kept at this temperature for $6 \mathrm{~h}$. The samples with the carbon coating were labeled as $\mathrm{Al}_{2} \mathrm{O}_{3}$ @C- $T$, where $T$ is the temperature of the final treatment in argon.

After heating in argon at high temperature, some of the carbon-coated samples were subjected to the calcination in air at $700{ }^{\circ} \mathrm{C}$ (or $1180^{\circ} \mathrm{C}$ ) for $6 \mathrm{~h}$ in a muffle furnace to burn off the carbon. Such samples were designated as $\mathrm{Al}_{2} \mathrm{O}_{3} @ \mathrm{C}-T_{1}-T_{2}$, where $T_{1}$ is the temperature of the heat treatment in argon and $T_{2}$ is the temperature of subsequent calcination in air.

In order to elucidate the effect of carbon shell, the reference alumina sample without carbon coating was also subjected to the similar thermal treatment procedures. Such samples were denoted as $\mathrm{Al}_{2} \mathrm{O}_{3}-T$, where $T$ is the thermal treatment temperature.
To control the state of the active sites on the alumina surface, including the samples obtained from the carbon-coated alumina by burning off the carbon, a spin probe method yielding the information on the electron-donor and electronacceptor sites on the alumina surface was used. This method was described in detail elsewhere. ${ }^{27-30}$ Prior to adsorption of the probe molecules the samples were dehydrated in air at $500{ }^{\circ} \mathrm{C}$ for $12 \mathrm{~h}$. The electron-acceptor surface sites were studied using an antracene adsorption from $5 \times 10^{-2} \mathrm{M}$ solution in toluene. The electron-donor sites were characterized using adsorption of 1,3,5-trinitrobenzene from $2 \times 10^{-2} \mathrm{M}$ solution in toluene. The concentration of the ion-radicals was measured after maintaining the samples in the mentioned solutions at $80^{\circ} \mathrm{C}$ for $5 \mathrm{~h}$, thus providing the achievement of their utmost value.

The EPR spectra were recorded using an ERS-221 EPR spectrometer working in the X-band with typical microwave power of $3 \mathrm{~mW}$. The concentrations of the paramagnetic species were determined by a numerical double integration with baseline compensation. A dissolved stable nitroxide radical TEMPO was used for the calibration.

The specific surface areas calculated by the BET method and pore size distributions calculated by the BJH method were obtained from the data of low-temperature argon adsorption using an ASAP-2400 instrument.

The photoluminescence experiments were carried out under the atmospheric conditions at $290 \mathrm{~K}$ using a homemade spectrofluorimeter equipped with MDR-12 monochromator (LOMO), an LN/CCD-1100PF/UV (Princeton Instruments) spectroscopic camera and a set of UV-vis laser sources. A $514.5 \mathrm{~nm}$ line of Ar ion laser LGN-402 (Russia) was used for the luminescence excitation. A powder sample was placed in a $1 \mathrm{~mm}$ deep quartz cell in a front-face configuration. The $\mathrm{Al}_{2} \mathrm{O}_{3}-1200$ sample was used for relative calibration of the PL method in determination of the $\alpha-\mathrm{Al}_{2} \mathrm{O}_{3}$ concentration.

UV-vis diffuse reflectance spectra were recorded between 200 and $800 \mathrm{~nm}$ using a Shimadzu UV-VIS 2501 PC spectrometer with IRS-250A diffusion reflection attachment. The UV-vis spectra were transformed into the Kubelka-Munk function $F(R)$ calculated as $F(R)=(1-R)^{2} / 2 R$, where $R$ is the experimentally measured reflectivity coefficient of the samples.

Raman spectra were recorded using a LabRAM HR800 spectrometer from HORIBA Jobin Yvon with a Symphony CCD detector. For spectral excitation the $488 \mathrm{~nm}$ line of an $\mathrm{Ar}$ ion laser (35LAP431 from Melles Griot, USA) was used. All data were collected using a Raman microscope in backscattering geometry. Spectral resolution was $1 \mathrm{~cm}^{-1}$.

XRD analysis was performed using a Brucker D8 diffractometer with $\mathrm{Co} \mathrm{K} \alpha$ irradiation. The high-resolution transmission electron microscopy (HR TEM) images were obtained using a JEM-2010CX microscope with a $1.4 \AA$ line resolution.

\section{Results and discussion}

\subsection{Stabilizing the alumina with the carbon coating}

The calcination of the nanocrystalline alumina samples at high temperatures is known to result in their conversion to a corundum phase with significant loss of the specific surface 
area and growth of the particle size. So, on the first stages of the research the effect of the carbon shell on the alumina phase transformations was studied. The carbon coating was found to hinder the sintering process of the $\mathrm{Al}_{2} \mathrm{O}_{3}$ nanoparticles without reacting with them within the studied temperature range.

It is well known that an increase of the size of the nanoparticles during the thermal treatment results in the loss of their specific surface area. The values of SSA for the studied samples after the calcination at high temperatures are shown in Fig. 1. Fast drop of the SSA at the calcination temperatures around $1100{ }^{\circ} \mathrm{C}$, when the corundum phase is formed, is evidently seen for pure $\mathrm{Al}_{2} \mathrm{O}_{3}$. At the same time, for the $\mathrm{Al}_{2} \mathrm{O}_{3}$ @C samples, relatively high values of SSA are preserved until the calcination temperature of $1380{ }^{\circ} \mathrm{C}$.

The pore size distributions for the $\mathrm{Al}_{2} \mathrm{O}_{3}$ and $\mathrm{Al}_{2} \mathrm{O}_{3} @ \mathrm{C}$ samples after different treatments are demonstrated in Fig. 2. The graphs were plotted in accordance with the IUPAC recommendations. ${ }^{31}$ The initial $\mathrm{Al}_{2} \mathrm{O}_{3}-720$ sample has the SSA close to $200 \mathrm{~m}^{2} \mathrm{~g}^{-1}$ and the mesopore volume equal to $0.55 \mathrm{~cm}^{3} \mathrm{~g}^{-1}$ with a peak on the pore size distribution at about $9 \mathrm{~nm}$ (Fig. 2A). After the thermal treatment at $1030{ }^{\circ} \mathrm{C}$, when the $\delta-\mathrm{Al}_{2} \mathrm{O}_{3}$ phase is

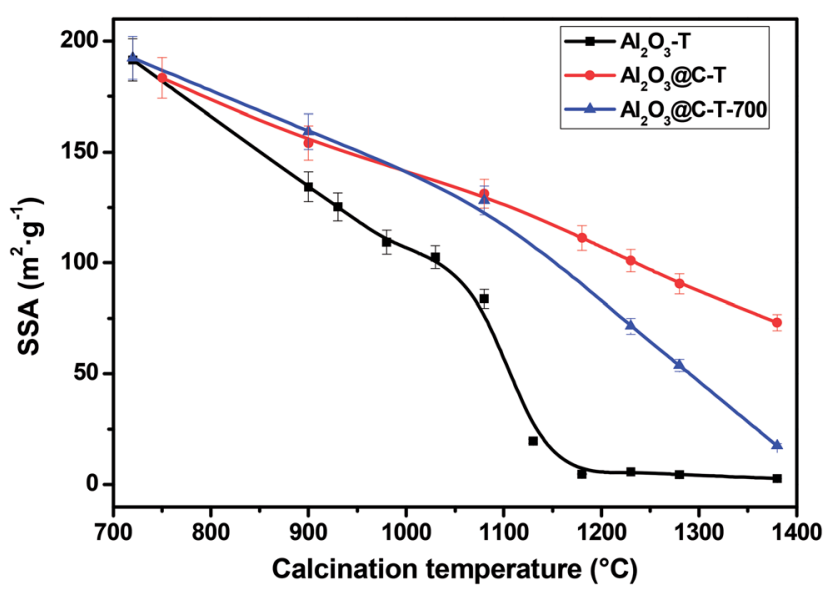

Fig. 1 Effect of the calcination temperature on the specific surface area of the $\mathrm{Al}_{2} \mathrm{O}_{3}$ and $\mathrm{Al}_{2} \mathrm{O}_{3} \mathrm{OC}$ samples, and the $\mathrm{Al}_{2} \mathrm{O}_{3} \mathrm{OC}$ samples calcined at $700{ }^{\circ} \mathrm{C}$ in air. formed, the mesopore structure is preserved. The SSA decreases to $c a .100 \mathrm{~m}^{2} \mathrm{~g}^{-1}$ with the pore volume of $0.45 \mathrm{~cm}^{3} \mathrm{~g}^{-1}$. The maximum on the pore size distribution shifts to $11.5 \mathrm{~nm}$. Meanwhile, the conversion of alumina to $\alpha-\mathrm{Al}_{2} \mathrm{O}_{3}$ after the calcination at $1250{ }^{\circ} \mathrm{C}$ leads to a collapse of the pore structure with the surface area going down to $5 \mathrm{~m}^{2} \mathrm{~g}^{-1}$ and pore volume decreasing to $0.05 \mathrm{~cm}^{3} \mathrm{~g}^{-1}$.

The pore size distribution for the carbon coated $\mathrm{Al}_{2} \mathrm{O}_{3} @ \mathrm{C}$ 720 looks very similar to that of the $\mathrm{Al}_{2} \mathrm{O}_{3}-720$ precursor before the carbon deposition (Fig. 2B). After the thermal treatment of the carbon-coated sample at $1250{ }^{\circ} \mathrm{C}$, the mesopore structure is preserved. The properties of this material resemble those of pure alumina calcined at $1030{ }^{\circ} \mathrm{C}$. It has the $\delta-\mathrm{Al}_{2} \mathrm{O}_{3}$ phase with the SSA equal to $100 \mathrm{~m}^{2} \mathrm{~g}^{-1}$, the mesopore volume of $0.27 \mathrm{~cm}^{3} \mathrm{~g}^{-1}$ with a peak on the pore size distribution at $13 \mathrm{~nm}$. Overall, the adsorption data confirm that the carbon coating makes it possible to stabilize the $\mathrm{Al}_{2} \mathrm{O}_{3}$ mesopore structure after the calcination at temperatures as high as $1250{ }^{\circ} \mathrm{C}$ and extend the temperature range of its existence by about $200{ }^{\circ} \mathrm{C}$.

The peculiarities of the phase transformations of pure and carbon-coated alumina samples at 1180,1250 and $1380{ }^{\circ} \mathrm{C}$ were studied by means of the X-ray diffraction analysis. The resulted XRD patterns are given in Fig. 3. Practically complete conversion to $\alpha-\mathrm{Al}_{2} \mathrm{O}_{3}$ (corundum) was observed for the pure $\mathrm{Al}_{2} \mathrm{O}_{3}$ sample already at $1180{ }^{\circ} \mathrm{C}$. At the same time, no noticeable amounts of corundum were formed in the case of the carbon-coated $\mathrm{Al}_{2} \mathrm{O}_{3}$ @C sample even at $1250{ }^{\circ} \mathrm{C}$. According to the XRD data presented in Fig. 3, only the $\delta-\mathrm{Al}_{2} \mathrm{O}_{3}$ phase was observed there.

The effect of the carbon coating on the formation of $\theta$ - and $\alpha$ $\mathrm{Al}_{2} \mathrm{O}_{3}$ phases at the initial stages, when the alumina conversion is very low, was estimated using the photoluminescence spectroscopy. PL spectroscopy is known as a convenient and highly sensitive method of diagnostics for these phases. The appearance of easily identifiable $R_{\alpha}$ lines of impurity $\mathrm{Cr}^{3+}$ ions, which are always present in alumina, was used as an inner probe. The procedure used to determine the concentrations of $\theta$ - and $\alpha$ $\mathrm{Al}_{2} \mathrm{O}_{3}$ phases in such samples is described elsewhere. ${ }^{32,33}$

The luminescence spectra of the pure alumina and the carbon-coated $\mathrm{Al}_{2} \mathrm{O}_{3} @ \mathrm{C}$ sample calcined in argon at $960{ }^{\circ} \mathrm{C}$ for $24 \mathrm{~h}$ are shown in Fig. 4. To perform the luminescence
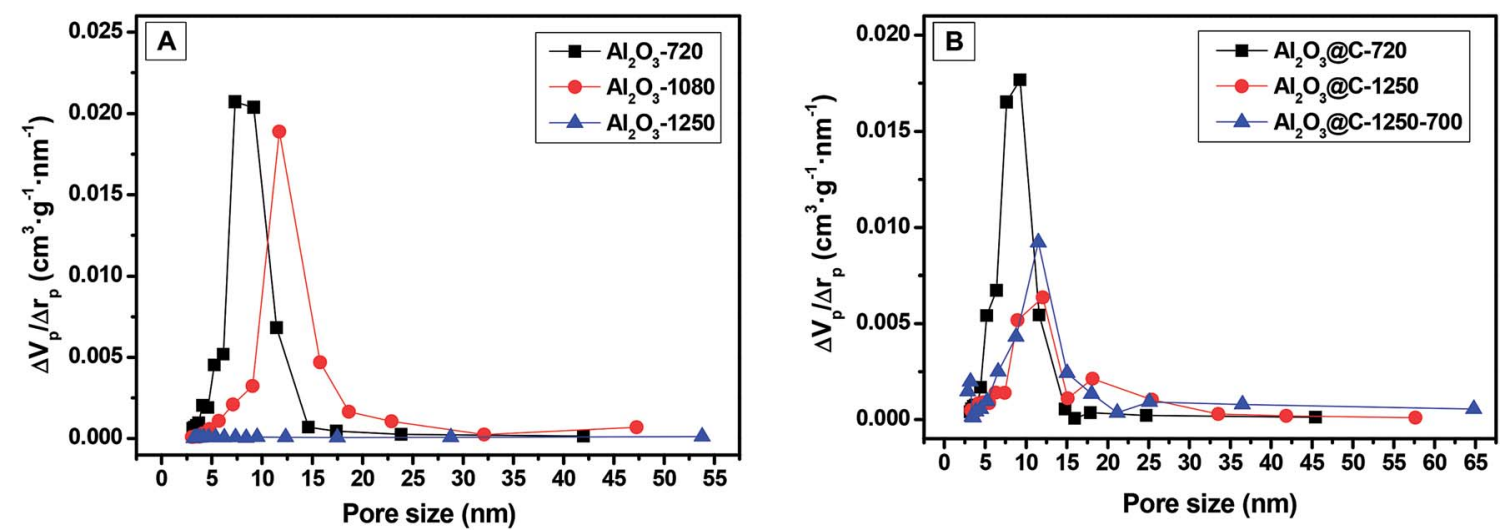

Fig. 2 Pore size distributions for the $\mathrm{Al}_{2} \mathrm{O}_{3}(\mathrm{~A})$ and $\mathrm{Al}_{2} \mathrm{O}_{3} \mathrm{CC}(\mathrm{B})$ samples after thermal treatment at different temperatures. 


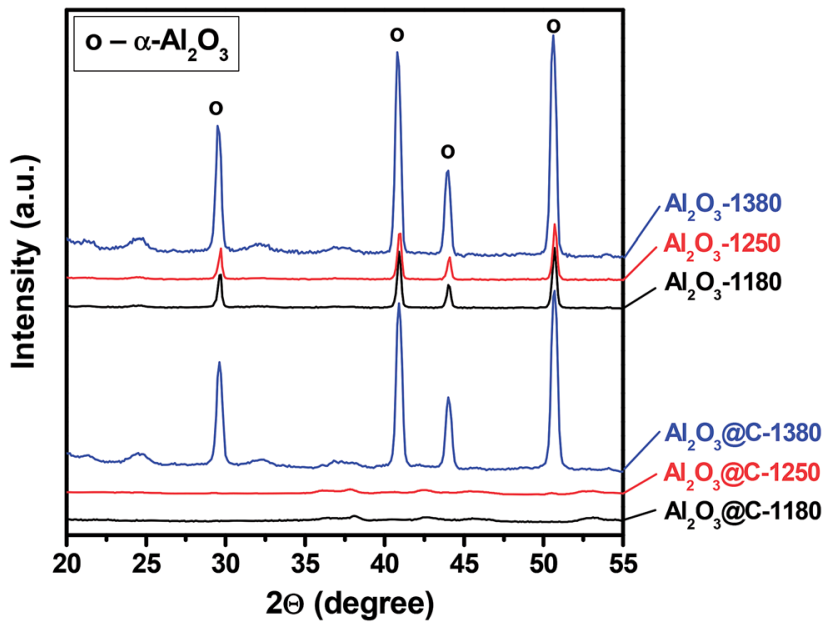

Fig. 3 XRD patterns of $\mathrm{Al}_{2} \mathrm{O}_{3}$ and $\mathrm{Al}_{2} \mathrm{O}_{3} @ \mathrm{C}$ samples after calcination at $1180{ }^{\circ} \mathrm{C}, 1250^{\circ} \mathrm{C}$ and $1380{ }^{\circ} \mathrm{C}$ for $6 \mathrm{~h} . \mathrm{Al}_{2} \mathrm{O}_{3}$ samples were calcined in air, whereas $\mathrm{Al}_{2} \mathrm{O}_{3} \mathrm{OC}$ samples were calcined in argon.

measurements, the carbon coating was removed by an additional calcination in air at $700{ }^{\circ} \mathrm{C}$.

Fig. 5 shows the effect of the calcination time on the concentrations of $\theta$ - and $\alpha-\mathrm{Al}_{2} \mathrm{O}_{3}$ phases in the samples estimated from the intensity of $\mathrm{Cr}^{3+} R_{\alpha}$ lines after excitation of $\mathrm{Cr}^{3+}$ ions in the ${ }^{4} \mathrm{~A}_{2} \rightarrow{ }^{4} \mathrm{~T}_{2}$ band $\left(\lambda_{\mathrm{ex}}=514.5 \mathrm{~nm}\right)$. It is evident that the carbon coating substantially slows down the rates of the $\theta$ and $\alpha-\mathrm{Al}_{2} \mathrm{O}_{3}$ phase's formation at the initial stages, thus

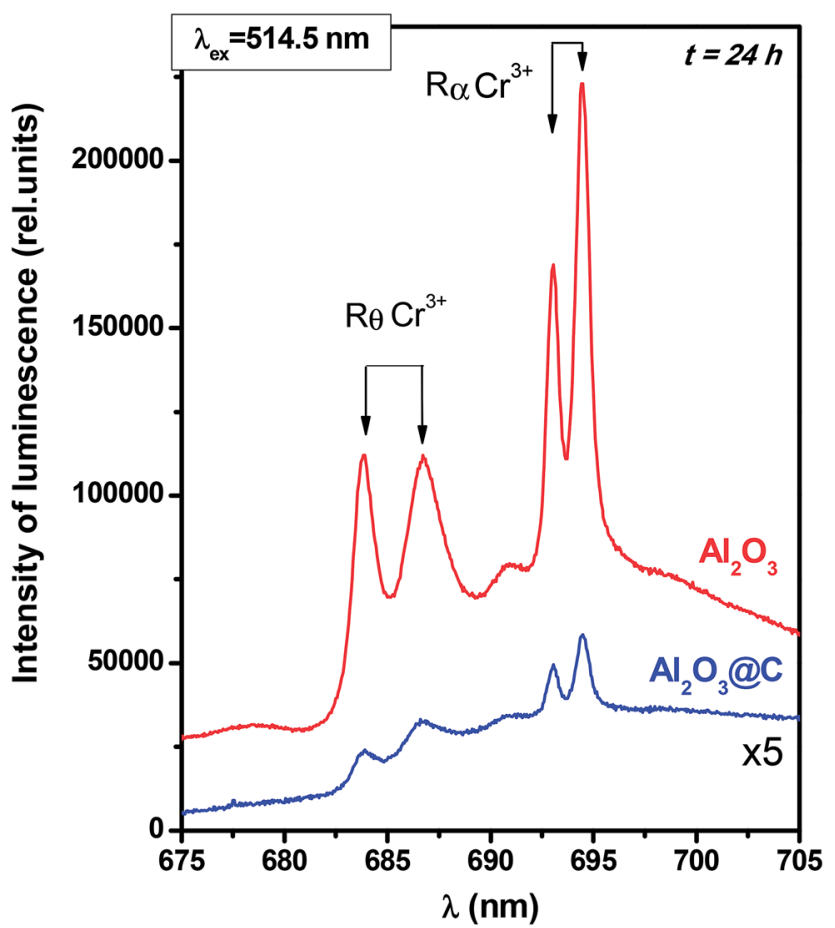

Fig. 4 Luminescence spectra for the $\mathrm{Al}_{2} \mathrm{O}_{3}$ and $\mathrm{Al}_{2} \mathrm{O}_{3} \mathrm{CC}$ samples calcined in argon at $960{ }^{\circ} \mathrm{C}$ for $24 \mathrm{~h}$. Prior to the luminescence measurements the carbon coating of the $\mathrm{Al}_{2} \mathrm{O}_{3} \mathrm{CC}$ sample was removed by calcination in air at $700^{\circ} \mathrm{C}$ for $6 \mathrm{~h}$.

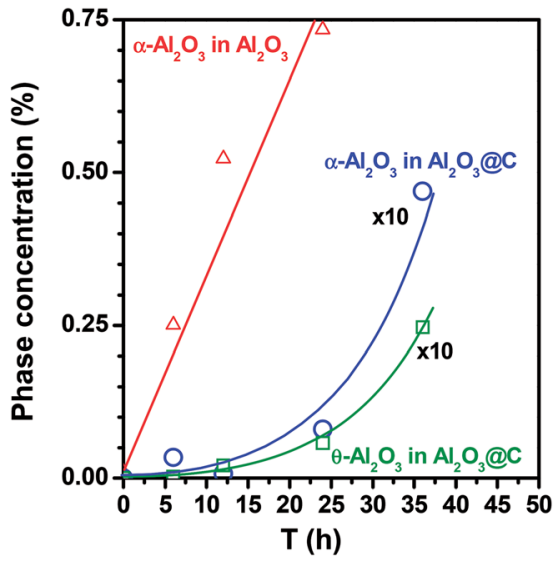

Fig. 5 The dependence of the corundum phase concentration in the $\mathrm{Al}_{2} \mathrm{O}_{3}$ and $\mathrm{Al}_{2} \mathrm{O}_{3} \mathrm{CC}$ samples, and $\theta$-phase in the $\mathrm{Al}_{2} \mathrm{O}_{3} \mathrm{CC}$ sample estimated from the intensities of $R_{\alpha}$ and $R_{\theta}$ lines of $\mathrm{Cr}^{3+}$ ions after excitation in ${ }^{4} \mathrm{~A}_{2} \rightarrow{ }^{4} \mathrm{~T}_{2}$ bands $\left(\lambda_{\text {ex }}=514.5 \mathrm{~nm}\right)$. For the $\mathrm{Al}_{2} \mathrm{O}_{3} \mathrm{QCC}$ sample, all the data were multiplied by a factor of 10 .

hindering ultimately the phase transformation. Note that in this concentration range it is practically impossible to detect the $\theta$ - and $\alpha-\mathrm{Al}_{2} \mathrm{O}_{3}$ phases by means of XRD analysis.

The size of the alumina crystallites is stabilized at level of 15$20 \mathrm{~nm}$ under such conditions (Fig. 6A). The HR TEM images clearly demonstrate the presence of disordered carbon in the form of the curved graphene packages on the surface of the alumina crystallites and inside the pores within them. The insertion in Fig. 6A presents the two-dimensional Fouriertransform from the selected area. The halo corresponds to the disordered carbon, and the pointed reflection conforms to lattice spacing $d_{013}=0.455 \mathrm{~nm}$ for the $\delta-\mathrm{Al}_{2} \mathrm{O}_{3}$ phase (PDF Data Base, card 46-1131).

As it was shown above by XRD, the transformation of alumina to corundum in the case of the $\mathrm{Al}_{2} \mathrm{O}_{3} @ \mathrm{C}$ sample takes place only during the thermal treatment at $1380{ }^{\circ} \mathrm{C}$ (Fig. 3). The size of the alumina particles exceeds $100 \mathrm{~nm}$ (Fig. 7A), and a monolayer graphene coating is formed on its surface (Fig. 7B). Most likely, at this temperature the carbon species are deformed by redistribution on the $\mathrm{Al}_{2} \mathrm{O}_{3}$ surface and leave the surface of the oxide nanoparticles allowing their direct contact and consequent sintering. Finally, the process results in the formation of the corundum phase, which is thermodynamically more stable for the case of large alumina particles.

The presented data demonstrate that in the studied samples the deposited carbon species prevent the sintering of the $\delta-\mathrm{Al}_{2} \mathrm{O}_{3}$ nanoparticles and their conversion to corundum at $1250{ }^{\circ} \mathrm{C}$. Without such coating $\delta-\mathrm{Al}_{2} \mathrm{O}_{3}$ undergoes both the sintering and the complete transformation to corundum at substantially lower temperatures. Thereby, it can be concluded that the size stabilization of the $\mathrm{Al}_{2} \mathrm{O}_{3}$ nanoparticles in the $\mathrm{Al}_{2} \mathrm{O}_{3} @ \mathrm{C}$ samples is the key factor, which prevents their phase transformation.

\subsection{Elimination of the carbon coating}

In order to characterize the alumina nanoparticles stabilized in the carbon nanoreactor, the carbon was removed by the 

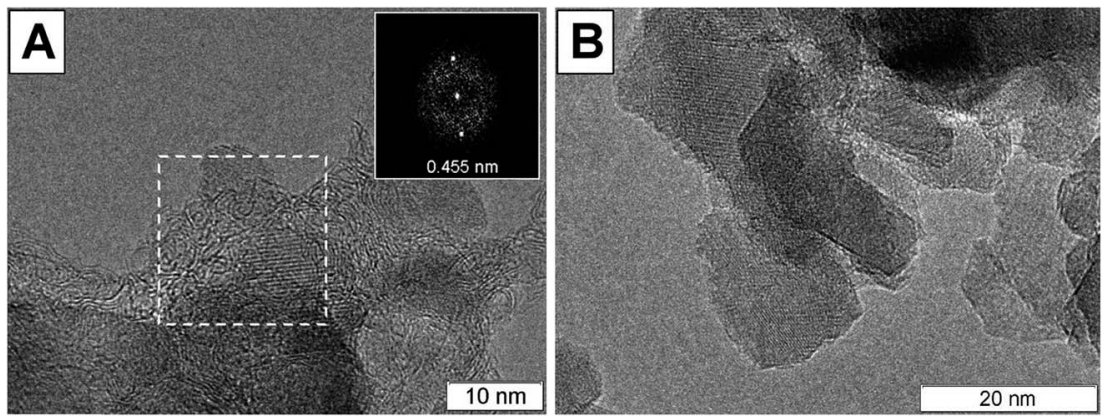

Fig. $6 \mathrm{HR}$ TEM images of the $\mathrm{Al}_{2} \mathrm{O}_{3} \mathrm{QC}$ sample after the calcination in argon at $1250{ }^{\circ} \mathrm{C}\left(\mathrm{Al}_{2} \mathrm{O}_{3} \mathrm{CC}-1250, \mathrm{~A}\right)$ and further calcination in air at $700{ }^{\circ} \mathrm{C}$ $\left(\mathrm{Al}_{2} \mathrm{O}_{3} \mathrm{aC}-1250-700, \mathrm{~B}\right)$. Insertion shows the two-dimensional Fourier-transform from the selected area.
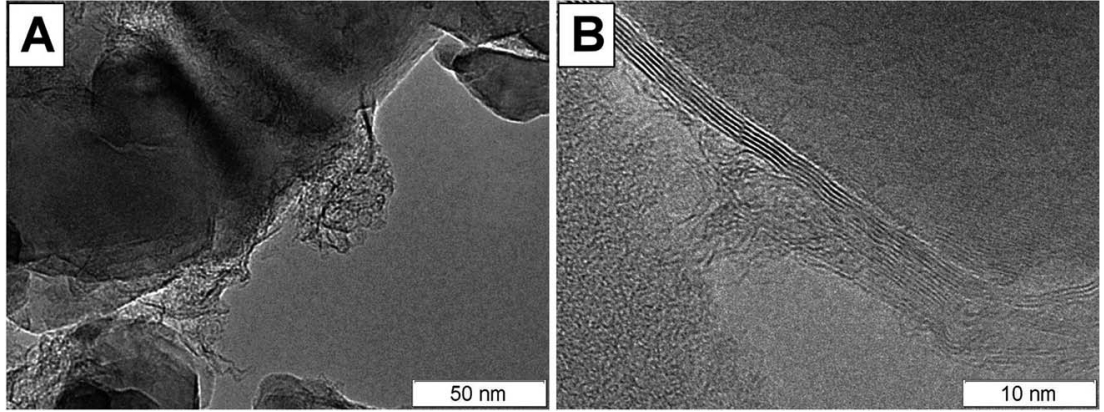

Fig. $7 \mathrm{HR}$ TEM images of $\mathrm{Al}_{2} \mathrm{O}_{3} \mathrm{CC}$ sample calcined in argon at $1380{ }^{\circ} \mathrm{C}\left(\mathrm{Al}_{2} \mathrm{O}_{3} \mathrm{CC}-1380\right)$.

calcination in air at $700{ }^{\circ} \mathrm{C}$. Fig. 1 also shows the comparison results for the SSA values of the carbon-coated samples before and after this procedure. As seen, starting from $1200^{\circ} \mathrm{C}$ carbon has a significant contribution to the specific surface area of the samples. At temperatures above $1300{ }^{\circ} \mathrm{C}$ its contribution exceeds that of the $\mathrm{Al}_{2} \mathrm{O}_{3}$ phase. Nevertheless, the SSA of the $\mathrm{Al}_{2} \mathrm{O}_{3}$ particles measured after the carbon coating removal by calcination in air at $700{ }^{\circ} \mathrm{C}$ remains relatively high even for the $\mathrm{Al}_{2} \mathrm{O}_{3} @ \mathrm{C}-1300$ samples. The calcination procedure eliminates the most of the deposited carbon, thus facilitating toward the preservation of the pore structure due to the carbon coating. After the calcination, the SSA remains as high as $72 \mathrm{~m}^{2} \mathrm{~g}^{-1}$ with the pore volume equal to $0.3 \mathrm{~cm}^{3} \mathrm{~g}^{-1}$ and a clear peak on the pore size distribution at $13 \mathrm{~nm}$ (Fig. 2B). According to TEM results, the carbon elimination procedure does not lead to the growth of the oxide nanoparticles (Fig. 6B). This image shows that all carbon accessible to the gas phase burns off during the calcination treatment. However, a minor fraction of carbon remains at the places of contact between the nanoparticles. These carbon species are believed to be responsible for the grey color of the samples and for the stabilization effect observed.

As it was already mentioned, finely dispersed alumina is quite often used as a catalyst or a catalyst support. Various types of the active sites on its surface might play an important role for such applications. From this point of view, it was important to study the effect of the high temperature calcination on the concentration of active sites present on the surface of the $\mathrm{Al}_{2} \mathrm{O}_{3} @ \mathrm{C}$ samples after the elimination of the carbon coating.
The electron-acceptor and electron-donor sites related to the strong surface acid and base sites, respectively, were characterized by EPR using appropriate spin probes. The $\delta-\mathrm{Al}_{2} \mathrm{O}_{3}$ sample with SSA about $100 \mathrm{~m}^{2} \mathrm{~g}^{-1}$ prepared by calcination of the initial $\mathrm{Al}_{2} \mathrm{O}_{3}$ precursor at $1000{ }^{\circ} \mathrm{C}$ was used as a reference.

The properties of such sites and the methods used for their characterization were reported in detail elsewhere. ${ }^{28-30,32}$ The electron-acceptor sites on the alumina surface characterized using the aromatic molecules (anthracene) were shown to correlate well with the acidic properties of this material and account for its catalytic activity in ethyl alcohol dehydration to ethylene. ${ }^{30}$ The electron-donor sites on the surface of alumina and zirconia are responsible for the stabilization of the atomically dispersed forms of deposited noble metals having high activity in a model reaction of $\mathrm{CO}$ oxidation and improved stability at elevated temperatures..$^{27,32,34,35}$

Typical EPR spectra observed after the anthracene adsorption on the surface electron-acceptor sites are shown in Fig. 8A. The EPR signal of anthracene ionized on the electron-acceptor sites is observed as a singlet line with $g=2.003$ and line width about $8 \mathrm{G}$ for all studied samples containing such sites. The estimated concentrations of such sites are summarized in Table 1. Almost the same concentrations of the electronacceptor sites were measured for the $\mathrm{Al}_{2} \mathrm{O}_{3}-1000$ and $\mathrm{Al}_{2} \mathrm{O}_{3} @ \mathrm{C}-1250-700$ samples. Meanwhile, for the $\mathrm{Al}_{2} \mathrm{O}_{3}-1180$ sample, this concentration was below the detection limit. It testifies that the surface properties of the alumina particles in the $\mathrm{Al}_{2} \mathrm{O}_{3} @ \mathrm{C}$ sample with respect to the used probe molecule 

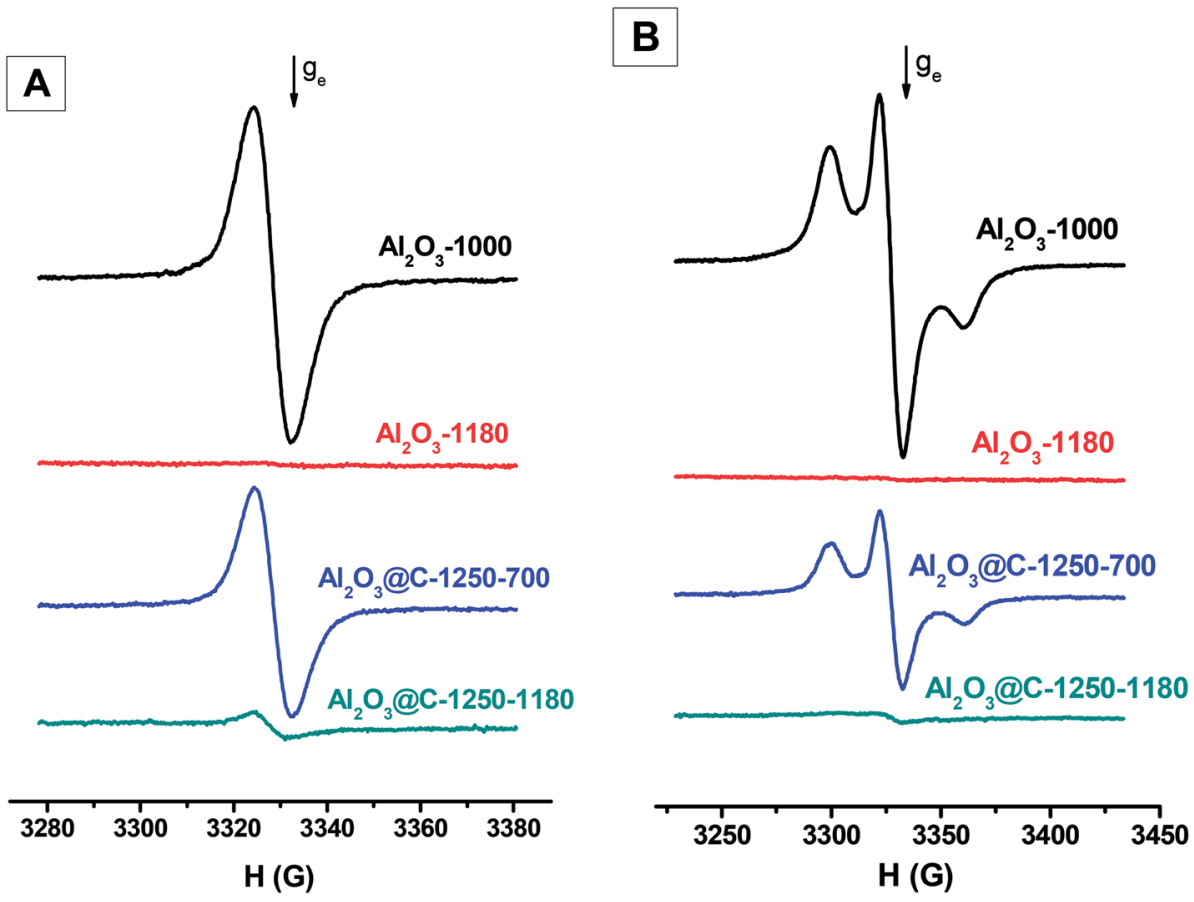

Fig. 8 EPR spectra of radicals registered after antracene $(A)$ and 1,3,5-trinitrobenzene (B) adsorption from toluene solution on the $\mathrm{Al}_{2} \mathrm{O}_{3}-1000$ and $\mathrm{Al}_{2} \mathrm{O}_{3}-1180$ samples, and the carbon-coated $\mathrm{Al}_{2} \mathrm{O}_{3} \mathrm{OC}-1250-700$ and $\mathrm{Al}_{2} \mathrm{O}_{3} \mathrm{OC}-1250-1180$ samples after calcination in air at 700 and $1180{ }^{\circ} \mathrm{C}$.

Table 1 Concentrations of electron-acceptor and electron-donor sites over the $\mathrm{Al}_{2} \mathrm{O}_{3}$ and $\mathrm{Al}_{2} \mathrm{O}_{3} \mathrm{aC}$ samples

\begin{tabular}{lll}
\hline Sample & $\begin{array}{l}\text { Concentration of } \\
\text { electron-acceptor } \\
\text { sites, } \mathrm{g}^{-1}\end{array}$ & $\begin{array}{l}\text { Concentration of } \\
\text { electron-donor } \\
\text { sites, } \mathrm{g}^{-1}\end{array}$ \\
\hline $\mathrm{Al}_{2} \mathrm{O}_{3}-1000$ & $4.3 \times 10^{17}$ & $4.3 \times 10^{18}$ \\
$\mathrm{Al}_{2} \mathrm{O}_{3}-1180$ & $<10^{16}$ & $<10^{17}$ \\
$\mathrm{Al}_{2} \mathrm{O}_{3}$ @C-1250-700 & $3.0 \times 10^{17}$ & $1.8 \times 10^{18}$ \\
$\mathrm{Al}_{2} \mathrm{O}_{3}$ @C-1250-1180 & $3.6 \times 10^{16}$ & $2.1 \times 10^{17}$
\end{tabular}

were not changed significantly even after the calcination at $1250{ }^{\circ} \mathrm{C}$. At the same time, conversion to the $\alpha-\mathrm{Al}_{2} \mathrm{O}_{3}$ phase and accompanying loss of the surface area has resulted in the disappearance of the surface electron-acceptor sites.

Typical EPR spectra observed after the 1,3,5-trinitrobenzene adsorption on the surface electron-acceptor sites are shown in Fig. 8B. These spectra correspond to TNB radical anions formed on the electron-donor sites of the $\mathrm{Al}_{2} \mathrm{O}_{3}$ surface that were reported in detail recently. ${ }^{28,29} \mathrm{~A}$ typical feature of these spectra is a hyperfine splitting on one nitrogen atom with strong anisotropy of the a-tensor. The $\mathrm{A}_{\mathrm{zz}}$ constant determined from the splitting between the extreme components of the spectra was equal to $31 \mathrm{G}$ for all the samples.

The results observed using this probe molecule are generally similar to the ones obtained by using anthracene, although the types of characterized active sites are entirely different. Hereby, the calcination of the carbon-coated alumina samples in argon at temperatures as high as $1250^{\circ} \mathrm{C}$ does not result in significant changes in the concentrations or properties of the electronacceptor or electron-donor sites on the surface of the alumina. The elimination of the carbon coating by the calcination in air leads to the alumina samples with the concentrations of these active sites, which are typical for the conventional $\delta-\mathrm{Al}_{2} \mathrm{O}_{3}$.

Quite different results were obtained for the $\mathrm{Al}_{2} \mathrm{O}_{3} @ \mathrm{C}-1250$ 1180 sample, which was calcined first in argon at $1250{ }^{\circ} \mathrm{C}$ and then in air at $1180^{\circ} \mathrm{C}$. As it was already noted, the concentrations of the studied active sites were below the detection limit for $\mathrm{Al}_{2} \mathrm{O}_{3}-1180$ sample without the carbon coating. It is in a good agreement with the data obtained by XRD and textural methods. The sample was completely converted to the $\alpha-\mathrm{Al}_{2} \mathrm{O}_{3}$ phase with a major loss of the surface area. Contrary, about $10 \%$ of the initial concentration of the active sites was detected on the $\mathrm{Al}_{2} \mathrm{O}_{3} @ \mathrm{C}-1250-1180$ sample. Thus, the thermal stability of $\mathrm{Al}_{2} \mathrm{O}_{3} @ \mathrm{C}-1250$ sample with respect to subsequent calcination in air was significantly higher than that of the pure alumina. Apparently, some carbon is retained in these samples after the procedure of the carbon coating elimination. These carbon species are presumably located at the places of contact between the crystallites and inaccessible to the air. They accounts for the grey color of these samples and significantly hinders their sintering at high temperatures.

This grey color appears only for $\mathrm{Al}_{2} \mathrm{O}_{3} @ \mathrm{C}-T$ samples calcined in argon at relatively high temperature $T$. Calcination of the initial $\mathrm{Al}_{2} \mathrm{O}_{3} @ \mathrm{C}-700$ sample in air at $700{ }^{\circ} \mathrm{C}$ results in complete combustion of the carbon deposits yielding a white sample. This observation was confirmed by the lack of additional absorption in the UV-vis and Raman spectra of this sample. 
DR UV-vis spectra for a series of the $\mathrm{Al}_{2} \mathrm{O}_{3}$ @C-T-700 samples $\left(T=1180,1230,1380\right.$ and $1450{ }^{\circ} \mathrm{C}$ are shown in Fig. 9). There are two bands in these spectra. A band at $250 \mathrm{~nm}$ can be assigned to the $\pi \rightarrow \pi *$ transition of graphitic C-C bonds. ${ }^{36-39} \mathrm{~A}$ band at 340-350 nm corresponds to $\mathrm{n} \rightarrow \mathrm{p}^{*}$ transition for isolated graphene particles and $\mathrm{C}-\mathrm{O}$ bonds ${ }^{40}$ on $\mathrm{Al}_{2} \mathrm{O}_{3}$ redshifted due to stronger interaction with the support from $\sim 300 \mathrm{~nm}$ and $330 \mathrm{~nm}$, respectively. The intensities of these lines increase with the growth of the calcination temperature in argon indicating increasing amount of carbon encapsulated during the sintering (Fig. 9). The growth of absorption in the whole spectral region of $450-850 \mathrm{~nm}$ can be related to the fact that the size and concentration of the carbon aggregates increase with rising the calcination temperature.

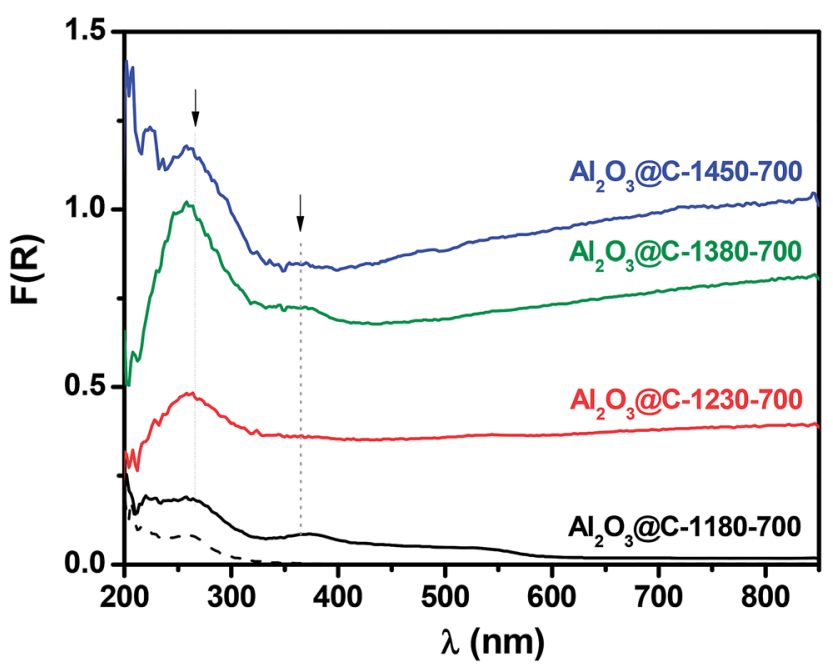

Fig. 9 DR UV-vis spectra of $\mathrm{Al}_{2} \mathrm{O}_{3} \mathrm{CC}-T-700$ samples calcined in argon at $1180{ }^{\circ} \mathrm{C}, 1230{ }^{\circ} \mathrm{C}, 1380^{\circ} \mathrm{C}$ and $1450{ }^{\circ} \mathrm{C}$ followed by calcination in air at $700{ }^{\circ} \mathrm{C}$. The spectrum of the pristine $\mathrm{Al}_{2} \mathrm{O}_{3}$ is shown by the dash line.

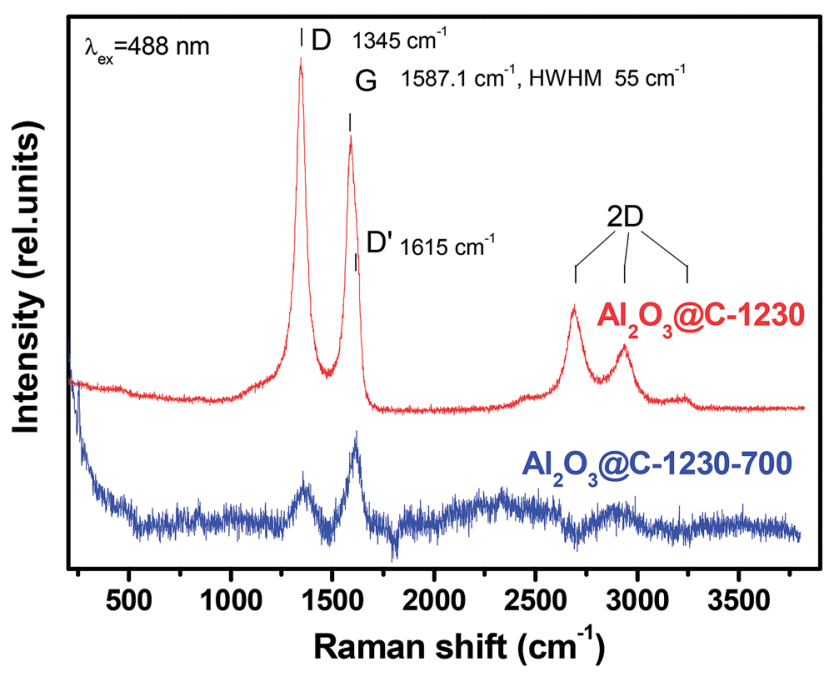

Fig. 10 Raman spectra of the $\mathrm{Al}_{2} \mathrm{O}_{3} @ \mathrm{CC}-1230$ and $\mathrm{Al}_{2} \mathrm{O}_{3} \mathrm{aC}-1230-700$ samples.
Raman spectroscopy yields averaged information on the state of the carbon shell in $\mathrm{Al}_{2} \mathrm{O}_{3} @ \mathrm{C}$ samples. The Raman spectra of the $\mathrm{Al}_{2} \mathrm{O}_{3}$ @C-1230 samples (Fig. 10) show welldeveloped D at $1350 \mathrm{~cm}^{-1}, \mathrm{G}$ at $1587 \mathrm{~cm}^{-1}, \mathrm{HWHM} \mathrm{G}-$ $55 \mathrm{~cm}^{-1}, \mathrm{D}^{\prime}$ at $1615 \mathrm{~cm}^{-1}$ and $2 \mathrm{D}$ peaks near $2700 \mathrm{~cm}^{-1}$. These data testify towards the formation of 1-3 monolayers of nanocrystalline graphite (nc-G). ${ }^{\mathbf{4 1 4 2}}$ According to the three-stage model of Ferrari and Robertson, ${ }^{42} I_{\mathrm{D}} / I_{\mathrm{G}}$ can be used to estimate the $\mathrm{sp}^{2}$-bonded cluster size or in-plane correlation length. From the ratio of $\mathrm{D}$ and $\mathrm{G}$ peak intensities, the in-plane correlation length of nc-G for $\mathrm{Al}_{2} \mathrm{O}_{3} @ \mathrm{C}-1230$ is presumed to be about $L_{\mathrm{a}} \sim 20 \AA^{42}$

The presented data are in a good agreement with the data obtained by other authors for nanocrystalline graphite films on the sapphire substrates prepared by a molecular beam epitaxy, ${ }^{\mathbf{4 3}}$ and via CVD on amorphous $\mathrm{Al}_{2} \mathrm{O}_{3}$ substrate ${ }^{40}$ synthesized within the same temperature range. The Raman spectra of the $\mathrm{Al}_{2} \mathrm{O}_{3} @ \mathrm{C}-1230-700$ sample, where carbon accessible to the gas phase was burned off by the calcination in air, is shown in Fig. 10. This spectrum is characterized by the lack of $2 \mathrm{D}$ peaks and substantially less intense D and $\mathrm{G}$ lines in comparison with the carbon-coated sample, and can be attributed to the nc-G particles (Fig. 6B) encapsulated at the places of contact between the alumina nanoparticles (carbon-alumina interfaces), which, as it was mentioned above, account for the grey color of the samples and absorption observed in the DR UV-vis spectra (Fig. 9).

\section{Conclusions}

The effect of carbon coating on the stability of the alumina nanoparticles was investigated. The obtained data demonstrate that the deposited carbon prevents the sintering of the $\delta-\mathrm{Al}_{2} \mathrm{O}_{3}$ nanoparticles and their transformation to corundum accompanied by the particle growth and loss of the specific surface area and the pore volume until the temperature of $1250{ }^{\circ} \mathrm{C}$. Without the carbon shell, $\delta-\mathrm{Al}_{2} \mathrm{O}_{3}$ is completely converted to the $\alpha-\mathrm{Al}_{2} \mathrm{O}_{3}$ phase after treatment at $1180{ }^{\circ} \mathrm{C}$ whereas the treatment at $1380^{\circ} \mathrm{C}$ is required for the same processes to take place in the case of the carbon-coated material. The stabilization of the particle size by the carbon shell in the $\mathrm{Al}_{2} \mathrm{O}_{3}$ @C samples is considered as a main factor preventing their phase transformation to corundum.

Further investigation of the thermal stability and properties of the $\mathrm{Al}_{2} \mathrm{O}_{3} @ \mathrm{C}$ samples heated in an argon flow within a temperature range of $1180-1250{ }^{\circ} \mathrm{C}$ followed by calcination in air to remove the carbon seems to be of considerable interest. Such samples are characterized by an appearance of the carbon-alumina interfaces, which is connected with the presence of the carbon encapsulated in small amounts at the places of contact between the nanoparticles and preventing their sintering. Such carbon-doped samples appear to have significantly higher stability with respect to the calcination in the oxygencontaining atmosphere at high temperatures if compare with the initial pure alumina. Note that the active sites on the surface of the alumina in the $\mathrm{Al}_{2} \mathrm{O}_{3}$ @C samples are similar to those present on the surface of the pristine $\mathrm{Al}_{2} \mathrm{O}_{3}$. These results 
suggest that such samples can be used as the catalyst supports or catalysts to be applied at elevated temperatures.

\section{Conflicts of interest}

There are no conflicts to declare.

\section{Abbreviations}

$\begin{array}{ll}\text { PVA } & \text { Polyvinyl alcohol } \\ \text { SSA } & \text { Specific surface area } \\ \text { PL } & \text { Photoluminescence } \\ \text { XRD } & \text { X-ray diffraction } \\ \text { HRTEM } & \text { High-resolution transmission electron microscopy } \\ \text { EPR } & \text { Electron paramagnetic resonance }\end{array}$

\section{Acknowledgements}

Financial support from Russian Science Foundation (grant 1613-10168) is acknowledged with gratitude.

\section{References}

1 I. V. Mishakov, A. F. Bedilo, R. M. Richards, V. V. Chesnokov, A. M. Volodin, V. I. Zaikovskii, R. A. Buyanov and K. J. Klabunde, J. Catal., 2002, 206, 40-48.

2 B. M. Choudary, R. S. Mulukutla and K. J. Klabunde, J. Am. Chem. Soc., 2003, 125, 2020-2021.

3 I. V. Mishakov, A. A. Vedyagin, A. F. Bedilo, V. I. Zailovskii and K. J. Klabunde, Catal. Today, 2009, 144, 278-284.

4 K. J. Klabunde, J. Stark, O. Koper, C. Mohs, D. G. Park, S. Decker, Y. Jiang, I. Lagadic and D. Zhang, J. Phys. Chem., 1996, 100, 12142-12153.

5 R. Richards, W. F. Li, S. Decker, C. Davidson, O. Koper, V. Zaikovski, A. Volodin, T. Rieker and K. J. Klabunde, J. Am. Chem. Soc., 2000, 122, 4921-4925.

6 G. W. Wagner, L. R. Procell, R. J. O'Connor, S. Munavalli, C. L. Carnes, P. N. Kapoor and K. J. Klabunde, J. Am. Chem. Soc., 2001, 123, 1636-1644.

7 A. F. Bedilo, M. J. Sigel, O. B. Koper, M. S. Melgunov and K. J. Klabunde, J. Mater. Chem., 2002, 12, 3599-3604.

8 I. V. Mishakov, V. I. Zaikovskii, D. S. Heroux, A. F. Bedilo, V. V. Chesnokov, A. M. Volodin, I. N. Martyanov, S. V. Filimonova, V. N. Parmon and K. J. Klabunde, J. Phys. Chem. B, 2005, 109, 6982-6989.

9 E. V. Ilyina, I. V. Mishakov, A. A. Vedyagin, A. F. Bedilo and K. J. Klabunde, Microporous Mesoporous Mater., 2013, 175, 76-84.

10 A. F. Bedilo, E. I. Shuvarakova, A. M. Volodin, E. V. Ilyina, I. V. Mishakov, A. A. Vedyagin, V. V. Chesnokov, D. S. Heroux and K. J. Klabunde, J. Phys. Chem. C, 2014, 118, 13715-13725.

11 H. Zhang and J. F. Banfield, J. Mater. Chem., 1998, 8, 20732076.

12 H. Zhang, B. Chena and J. F. Banfield, Phys. Chem. Chem. Phys., 2009, 11, 2553-2558.
13 H. Zhang and J. F. Banfield, Chem. Rev., 2014, 114, 96139644.

14 J. M. McHale, A. Auroux, A. J. Perrotta and A. Navrotsky, Science, 1997, 277, 788-791.

15 J. M. McHale, A. Navrotsky and A. J. Perrotta, J. Phys. Chem. B, 1997, 101, 603-613.

16 R. H. R. Castro, S. V. Ushakov, L. Gengembre, D. Gouvea and A. Navrotsky, Chem. Mater., 2006, 18, 1867-1872.

17 R. H. R. Castro, Mater. Lett., 2013, 96, 45-56.

18 N. G. Ivanova, N. A. Vasil'eva, R. A. Buyanov, M. M. Andrushkevich and E. A. Levitskii, Kinet. Katal., 1972, 13, 1033-1035.

19 R. A. Buyanov and A. D. Afanas'ev, Kinet. Katal., 1975, 16, 802-803.

20 A. M. Volodin, V. I. Zaikovskii, R. M. Kenzhin, A. F. Bedilo, I. V. Mishakov and A. A. Vedyagin, Mater. Lett., 2017, 189, 210-212.

21 S. Liu, Y.-H. Sun, F.-C. Zhou and J.-M. Nan, Appl. Surf. Sci., 2016, 375, 101-109.

22 M. A. Mohamed, W. N. W. Salleh, J. Jaafar, M. S. Rosmi, Z. A. M. Hir, M. A. Mutalib, A. F. Ismail and M. Tanemura, Appl. Surf. Sci., 2017, 393, 46-59.

23 W. Zhang, Y. Wang, M. Xie and X. Guo, Mater. Lett., 2016, 163, 122-125.

24 K. W. Tan, H. Sai, S. W. Robbins, J. G. Werner, T. N. Hoheisel, S. A. Hesse, P. A. Beaucage, F. J. DiSalvo, S. M. Gruner, M. Murtagh and U. Wiesner, RSC Adv., 2015, 5, 49287-49294.

25 A. M. Volodin, A. F. Bedilo, I. V. Mishakov, V. I. Zaikovskii, A. A. Vedyagin, R. M. Kenzhin, V. O. Stoyanovskii and K. S. Golohvast, Nanotechnol. Russ., 2014, 9, 700-706.

26 D. S. Heroux, A. M. Volodin, V. I. Zaikovskii, V. V. Chesnokov, A. F. Bedilo and K. J. Klabunde, J. Phys. Chem. B, 2004, 108, 3140-3144.

27 A. A. Vedyagin, A. M. Volodin, V. O. Stoyanovskii, I. V. Mishakov, D. A. Medvedev and A. S. Noskov, Appl. Catal., B, 2011, 103, 397-403.

28 D. A. Medvedev, A. A. Rybinskaya, R. M. Kenzhin, A. M. Volodin and A. F. Bedilo, Phys. Chem. Chem. Phys., 2012, 14, 2587-2598.

29 A. F. Bedilo, E. I. Shuvarakova, A. A. Rybinskaya and D. A. Medvedev, J. Phys. Chem. C, 2014, 118, 15779-15794.

30 R. A. Zotov, V. V. Molchanov, A. M. Volodin and A. F. Bedilo, J. Catal., 2011, 278, 71-77.

31 K. S. W. Sing, D. H. Everett, R. A. W. Haul, L. Moscou, R. A. Pierotti, J. Rouquerol and T. Siemieniewska, Pure Appl. Chem., 1985, 57, 603-619.

32 V. O. Stoyanovskii, A. A. Vedyagin, G. I. Aleshina, A. M. Volodin and A. S. Noskov, Appl. Catal., B, 2009, 90, 141-146.

33 V. N. Snytnikov, V. O. Stoyanovskii, T. V. Larina, O. P. Krivoruchko, V. A. Ushakov and V. N. Parmon, Kinet. Catal., 2008, 49, 291-298.

34 A. A. Vedyagin, A. M. Volodin, R. M. Kenzhin, V. O. Stoyanovskii, Y. V. Shubin, P. E. Plyusnin and I. V. Mishakov, Catal. Today, 2017, 293-294, 73-81. 
35 A. A. Vedyagin, A. M. Volodin, R. M. Kenzhin, V. O. Stoyanovskii, V. A. Rogov, V. V. Kriventsov and I. V. Mishakov, Catal. Today, 2017, DOI: 10.1016/ j.cattod.2017.01.033.

36 C. Jäger, T. Henning, R. Schlögl and O. Spillecke, J. NonCryst. Solids, 1999, 258, 161-179.

37 E. A. Taft and H. R. Philipp, Phys. Rev., 1965, 138, A197-A202. 38 A. B. Djurišić and E. H. Li, J. Appl. Phys., 1999, 85, 7404-7410. 39 S. Saxena, T. A. Tyson, S. Shukla, E. Negusse, H. Chen and J. Bai, Appl. Phys. Lett., 2011, 99, 013104.
40 J. Park, J. Lee, J.-H. Choi, D. K. Hwang and Y.-W. Song, Sci. Rep., 2015, 5, 11839.

41 A. C. Ferrari and J. Robertson, Phys. Rev. B, 2000, 61, 1409514107.

42 F. Tuinstra and J. L. Koenig, J. Chem. Phys., 1970, 53, 11261130.

43 S. K. Jerng, D. S. Yu, Y. S. Kim, J. Ryou, S. Hong, C. Kim, S. Yoon, D. K. Efetov, P. Kim and S. H. Chun, J. Phys. Chem. C, 2011, 115, 4491-4494. 